\title{
GNAS NM_000516.5:C.601C>A
}

National Cancer Institute

\section{Source}

National Cancer Institute. GNAS NM 000516.5:C.601C>A. NCI Thesaurus. Code C146961.

A nucleotide substitution at position 601 of the coding sequence of the GNAS gene where cytosine has been mutated to adenine. 